\title{
Quantitative Evaluation of Soil Erosion in the Upper Minjiang River Basin of China Based on Integration of Geospatial Technologies Using RUSLE
}

\author{
Hongmeng Ye ${ }^{1-3}$, Weiping Hua ${ }^{2}$, Changchun Huang ${ }^{1}$, Tao Huang ${ }^{1}$, \\ Hong Wang ${ }^{1}$, Xuyin Yuan ${ }^{2,3}$, Hao Yang ${ }^{1 * *}$ \\ ${ }^{1}$ School of Geography Science, Nanjing Normal University, Nanjing, China \\ ${ }^{2}$ Fujian Provincial Key Laboratory of Eco-Industrial Green Technology, College of Ecology \\ and Resource Engineering of Wuyi University, Wuyishan, China \\ ${ }^{3}$ College of the Environment, Hohai University, Nanjing, China
}

Received: 4 August 2019

Accepted: 15 November 2019

\begin{abstract}
Soil erosion is an important part of land ecological change and global environmental change. In southern China, the red soil hilly area is a region with serious soil erosion and water and soil loss. In this study, the spatial distribution of soil erosion and its change induced by land use types were obtained with the spatial operation analysis technology of a geographic information system and the revised universal soil loss equation model (RUSLE). The results show that soil erosion is most very lightly eroded in the study area as a whole, and has a wide yet relatively concentrated distribution, namely spatial aggregation distribution. The average soil erosion rate is the highest in Zhenghe County, followed by Wuyishan City, Shunchang County and Changting County, and relatively low in other counties. Further analysis on soil erosion under different land use types shows that erosion is more serious in unused land, orchard, dry land and rural settlements, and less severe in grassland, urban land, woodland and paddy field. This can be explained by the differences in vegetation cover, soil and water conservation measures, and the degree of human disturbance under different land use patterns.
\end{abstract}

Keywords: soil erosion, quantitative evaluation, land use type, the Upper Minjiang River Basin, RUSLE model 


\section{Introduction}

Soil erosion by water is an important part of land ecological change and global environmental change [1]. Considered as a multi-factor, multi-level and multiscale geo-scientific problem, soil erosion by water has major adverse effects on agricultural productivity and the sustainable use of surface water resources [2]. Strengthening the prevention and control of soil erosion is a fundamental guarantee to improve the quality of a regional ecological environment. At the same time, land use and land cover (LULC), as a comprehensive representation of human activities, not only profoundly affects the activities of vegetation litter, residues and soil microorganisms, but also causes differences in soil nutrient distribution and soil and water loss degree, thus changing the distribution, migration and translocation of carbon, nitrogen and phosphorus nutrients in soil, organisms and water [3-6]. In a sense, quantitative comparative analysis of soil erosion with the corresponding land use types can help to formulate more scientific and reasonable water and soil conservation and non-point source control measures in a watershed, and guide the optimization and adjustment of land use and agricultural structures. In addition, such analysis also provides information for simulating the output of large-scale non-point source pollution [7-9].

The soil erosion process and mechanism have been a hotspot in global research. To develop optimal soil erosion management plans, researchers worldwide have established a variety of soil erosion assessment methods in the past decades, including the universal soil loss equation (USLE) [10], the water erosion prediction project (WEPP) [11], the revised universal soil loss equation (RUSLE) [12], the European soil erosion model (EUROSEM) [13], the Chinese soil loss equation (CSLE) [14], and many others [15-16]. The study of soil erosion has evolved from empirical model to physical model, and from qualitative estimate to quantitative study [4-5]. Soil conservation actions over large areas are expensive and need to be targeted to obtain maximum benefit for least cost. With the development of remote sensing (RS), geographic information system (GIS) and computer image processing technology, it is possible to extract soil erosion factors quickly and accurately for regional soil erosion analysis and to update them in real time [5, 17-20].

Soil erosion continues to represent a major environmental issue in China. This is especially so in southern China, where the red soil hilly region is an area with serious soil erosion and water and soil loss. In recent years, many studies have been done on the law of soil and water loss, influencing factors, allowable loss, control measures and effects in the hilly region of red soil in southern China [21-23]. However, many fewer studies have reported the quantitative prediction of soil and water loss and the difference of soil erosion under many different land use types in the southern China red soil hilly regions at the large watershed scale.

The upstream watershed of the Minjiang River is not only a water source protection area with heavy precipitation and sufficient water resources, but also a key forest area in Fujian Province. It has typical characteristics of the red soil hilly region in southern China [4, 8, 24]. Soil erosion by water is a major agent of land degradation in this study area because of its steep slope and intense washout under heavy precipitation. However, no systematic studies with quantitative statistics have been done in the basin on soil erosion of different land use types. Based on GIS and RS technology, this study quantitatively evaluates the soil erosion in the upper Minjiang River basin by using the RUSLE model, and analyses the status of soil erosion and its response to land use types. The purpose

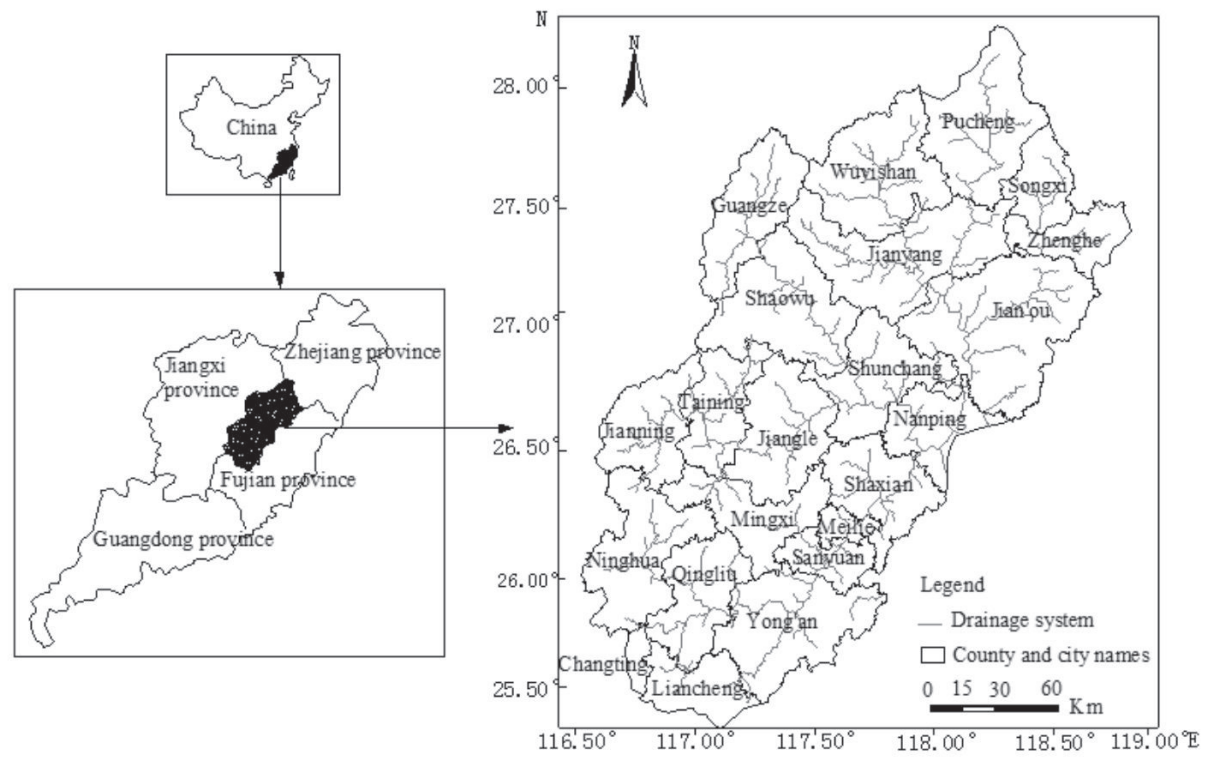

Fig. 1. Distribution of administrative divisions in the upstream watershed of the Minjiang River. 


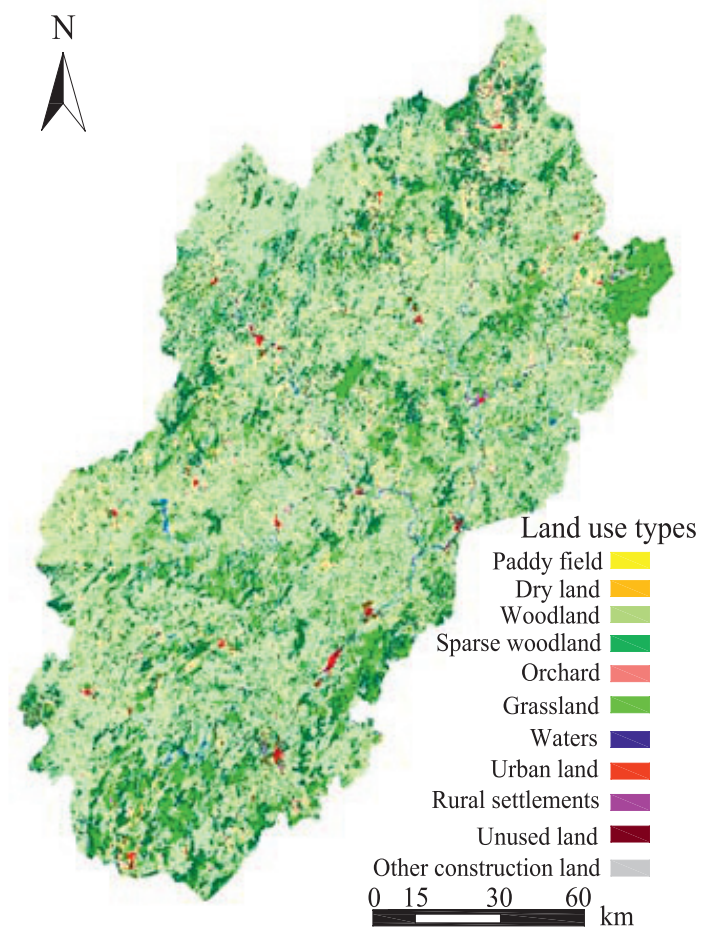

Fig. 2. Distribution of land use type in the upstream watershed of the Minjiang River.

of this study is to provide a decision-making basis and practical cases for water and soil conservation and ecological environmental protection in the basin, and to achieve good water resources, water ecology and water environment.

\section{Materials and Methods}

\section{Study Area}

Minjiang River is the "mother river" of Fujian Province. It has a total length of $562 \mathrm{~km}$ and a watershed area of $60992 \mathrm{~km}^{2}$, which accounts for $62.5 \%$ of Fujian's land area. The Minjiang River is divided into upper, middle and lower reaches by the boundaries at Nanping City and Shuikou Town, respectively. The upstream area covers 22 counties and cities (Fig. 1) and accounts for nearly $70 \%$ of the whole basin area. With an annual average rainfall of over $2000 \mathrm{~mm}$, the upstream area has an annual average runoff of $1056.7 \mathrm{~mm}$, and a total runoff accounting for about $75 \%$ of the total water volume in Minjiang River. Therefore, it is not surprising that the upstream watershed has a great impact on the ecological environment in the Minjiang River Basin and Fujian Province. The upstream basin is a typical hilly landform in southern China. Mountainous and hilly areas account for more than $80 \%$ of the land area. In the winding valleys and small inter-mountain basins, the terrain is complex and the soil is mainly zonal red soil.

\section{Research Model}

The soil erosion rate (A) is calculated with the RUSLE model, which has been applied to regions with different conditions all over the world, including mountainous regions, forests, rangelands, badlands, and heterogeneous areas $[16,25,26]$. The model estimates soil erosion as the linear product of five factors $(\mathrm{R}, \mathrm{K}$, Ls, C, and P), which represent the catchment's climatic, pedological, topographic, land cover, and anthropogenic characteristics [16, 27]. RUSLE can be expressed as follows:

$$
A=R \times K \times L_{S} \times C \times P
$$

...where $A$ stands for the soil erosion rate $\left(\mathrm{t} \cdot\left(\mathrm{hm}^{2} \cdot \mathrm{a}\right)^{-1}\right)$, $R$ is the rainfall erosion factor $\left(\mathrm{MJ} \cdot \mathrm{mm} \cdot\left(\mathrm{hm}^{2} \cdot \mathrm{h} \cdot \mathrm{a}\right)^{-1}\right)$, $K$ is the soil erodibility factor $\left(\mathrm{t} \cdot \mathrm{h} \cdot(\mathrm{MJ} \cdot \mathrm{mm})^{-1}\right), L_{S}$ is the topography factor (which includes slope length and steepness factor), $C$ is the cover management factor, and $P$ is the support and conservation practice factor. Among the parameters, $L_{S}, C$, and $P$ are dimensionless.

\section{Data Sources}

The research data are from Landsat- 8 satellite image data of 2015 (resolution: $30 \mathrm{~m}$ ), digital elevation data DEM for Google earth (resolution: $4 \mathrm{~m}$ ), vector map of soil type in Fujian Province, and rainfall data and related data of soil and water conservation from 2000 to 2015 in the study area.

Pre-processing of remote sensing image uses ENVI 5.2 software for image fusion, mosaic, clipping and other steps. The land use of the upstream watershed of the Minjiang was obtained by remote sensing interpretation, and classified into 11 categories according to the classification system of land use and cover classification of the Chinese Academy of Sciences (Fig. 2) by supervised classification operation. The land area percentage of woodland (natural and planted

Table 1. Soil erosion intensity classification criteria.

\begin{tabular}{|c|c|c|c|}
\hline Erosion degree & $\mathrm{A}\left(\mathrm{t} \cdot \mathrm{km}^{-2} \cdot \mathrm{a}^{-1}\right)$ & Erosion grade & $\mathrm{A}\left(\mathrm{t} \cdot \mathrm{km}^{-2} \cdot \mathrm{a}^{-1}\right)$ \\
\hline Very lightly eroded & $<500$ & Strongly eroded & $5000 \sim 8000$ \\
\hline Lightly eroded & $500 \sim 2500$ & Very strongly eroded & $>8000$ \\
\hline Moderately eroded & $2500 \sim 5000$ & & \\
\hline
\end{tabular}


forests with canopy density of more than 30\%), sparse woodland (forest with canopy density of less than $30 \%$ ) and grassland is $47.28 \%, 15.78 \%$ and $14.55 \%$, respectively. Paddy field, dry land and orchard are with less area percentages of $11.79 \%, 5.11 \%$ and $3.70 \%$, respectively. The total area percentage of all other land use types combined is less than $1 \%$.

\section{Evaluation and Classification}

According to previous studies [28], the area with severe erosion $\left(>15000 \mathrm{t} \cdot \mathrm{km}^{-2} \cdot \mathrm{a}^{-1}\right)$ is very small in

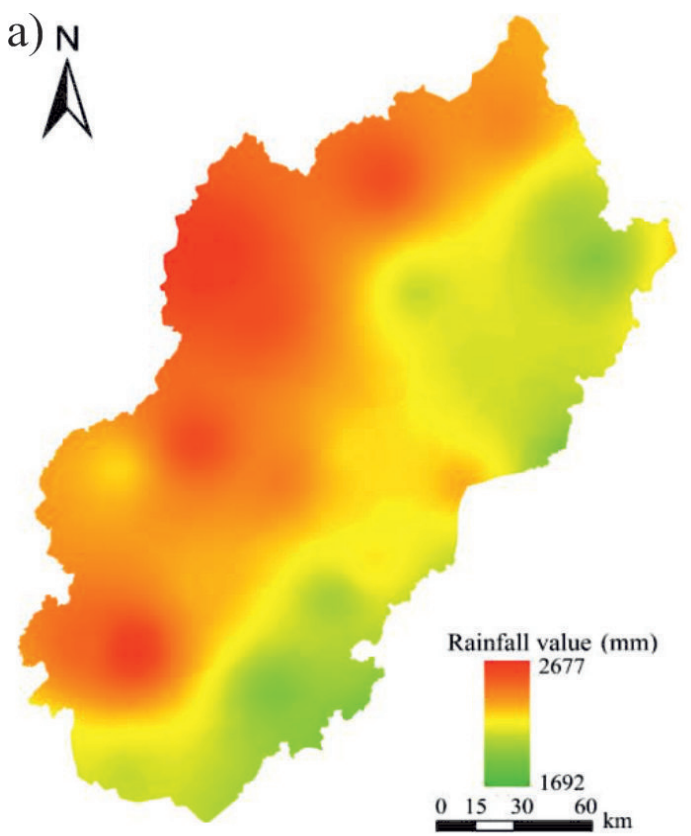

b)

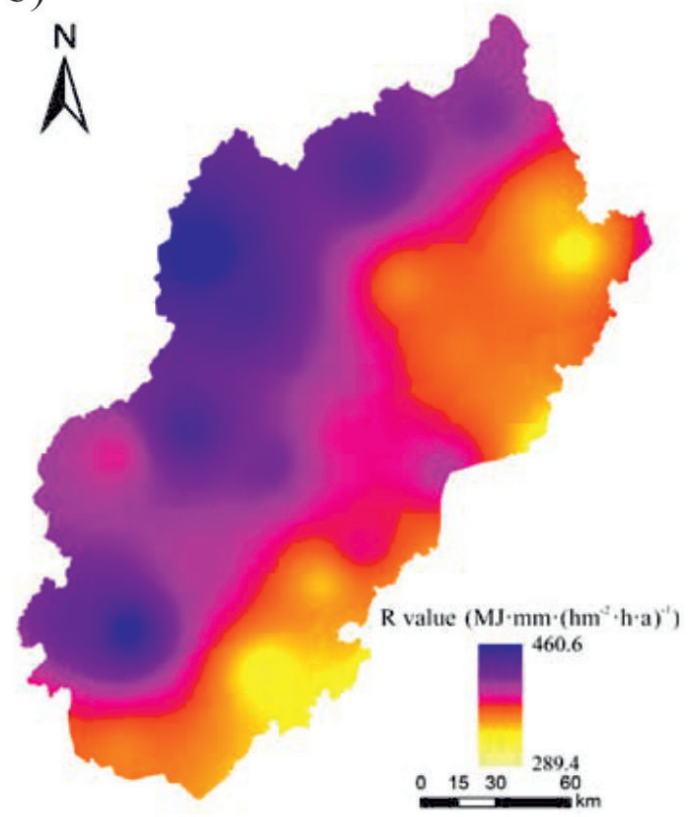

Fig. 3. Diagrams of rainfall and $\mathrm{R}$ values in the upstream watershed of the Minjiang River; a) Rainfall diagram, b) $\mathrm{R}$ diagram. the Minjiang River Basin. In the study area, the classification standard for soil erosion is determined to be in five levels according to average annual erosion (A) (detailed in Table 1), with reference to the "Classification and Classification Standard for Soil Erosion" (SL190-96) issued by the Ministry of Water Resources of China.

\section{Results and Discussion}

\section{Calculation and Spatial Distribution of Soil Erosion}

\section{Calculation and Results of Each Factor}

The factor of rainfall erosivitiy $(\mathrm{R})$ represents the ability of raindrops and rainfall-induced runoff to erode soil $[25,26]$. The value of $\mathrm{R}$ was calculated based on the precipitation information of the Minjiang River basin from 2000 to 2015. The calculation method was adopted because of the data availability and the wide application of the method $[10,29]$. Below is the formula for calculation:

$$
R=\sum_{i=1}^{12}\left\{1.735 \times 10^{\left[1.5 \times \log _{10}\left(\frac{p_{i}^{2}}{p}\right)\right]-0.8188}\right\}
$$

...where $R$ is the parameter for rainfall erosivity $\left(\mathrm{MJ} \cdot \mathrm{mm} \cdot\left(\mathrm{hm}^{2} \cdot \mathrm{h} \cdot \mathrm{a}\right)^{-1}\right), P_{i}$ represents the average monthly rainfall $(\mathrm{mm})$ for each month of the year, and $P$ is the average annual rainfall $(\mathrm{mm})$ over a certain time interval (Fig. 3a). The distribution of $\mathrm{R}$ is shown in Fig. 3b).

Soil erodibility $(\mathrm{K})$, which has important influence on the accuracy of soil loss prediction, is a critical factor in the universal soil loss equation (USLE) and the models modified from it $[6,25,26]$. This factor represents the effect of inherent soil properties on erosion processes and rates, and affects sediment delivery to streams and needs to be appropriately quantified and interpolated as a fundamental geographic variable for implementing suitable catchment management and conservation practices [16, 29]. Determined by the soil types and closely related to soil texture and soil organic matter content, $\mathrm{K}$ factor indicates the sensitivity of soil to rainfall erosion and the runoff magnitude and runoff rate by precipitation. Therefore, soil properties in the studied area (Fig. 4a) are usually used to estimate the values of $\mathrm{K}$. According to the field investigation and previous research results, the $\mathrm{K}$ values of various soil types in the basin are determined on a comprehensive basis. The $\mathrm{K}$ values of the main soil types are shown in Table 2. Based on the vector data of soil types in the study area, the $\mathrm{K}$ value in Table 2 was assigned to obtain the spatial distribution map of $\mathrm{K}$ value (Fig. 4b).

The topographic factor $\left(\mathrm{L}_{\mathrm{S}}\right)$ is an important hydraulic factor of soil erosion. $\mathrm{L}_{\mathrm{s}}$ is a highly sensitive 
Table 2. $\mathrm{K}$ values for the main soil types in the studied watershed.

\begin{tabular}{|c|c|c|c|c|c|}
\hline No. & Soil type & K value & No. & Soil type & K value \\
\hline 1 & Dark yellow-brown soil & 0.163 & 12 & Percogenic paddy soil & 0.188 \\
\hline 2 & Lime soil & 0.216 & 13 & Gleyed paddy soil & 0.180 \\
\hline 3 & Black calcareous soil & 0.202 & 14 & Red soil & 0.199 \\
\hline 4 & Purple soil & 0.213 & 15 & Yellow-red soil & 0.188 \\
\hline 5 & Acid purple soil & 0.205 & 16 & Red earth soil & 0.193 \\
\hline 6 & Acid lithic soil & 0.183 & 17 & Yellow soil & 0.158 \\
\hline 7 & Rhogosol & 0.185 & 18 & Yellow earth soil & 0.171 \\
\hline 8 & Acid rhogosol & 0.180 & 19 & Lake or reservoir & 0 \\
\hline 9 & Mountain meadow soil & 0.214 & 20 & Rivers & 0 \\
\hline 10 & Paddy soil & 0.185 & 21 & Sandbank & 0 \\
\hline 11 & Waterloggogenic paddy soil & 0.187 & & & \\
\hline
\end{tabular}

factor and represents the influencing degree of topographic conditions on hydraulic erosion $[16,26]$. Generally, topographic factors mainly include slope and slope length factors in order to reflect their contribution to soil erosion. In the upstream Minjiang watershed, many mountainous areas are with $>20^{\circ}$ slopes [24,
28]. Therefore, the slopes cannot be quantified by the slope factor formula of the U.S. general soil erosion equation (applicable for an area with a maximum slope of 15 degrees) [6, 30]. Instead, the empirical formula developed in the Fujian area is used for the calculation $[28,31]$ : a)

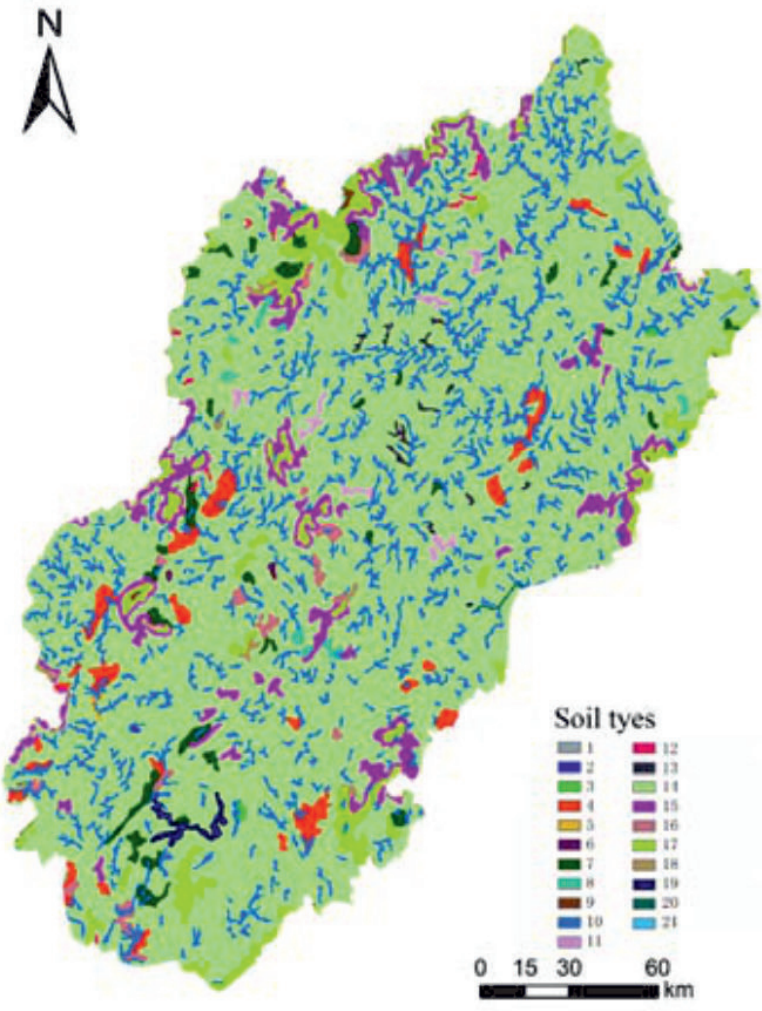

b)

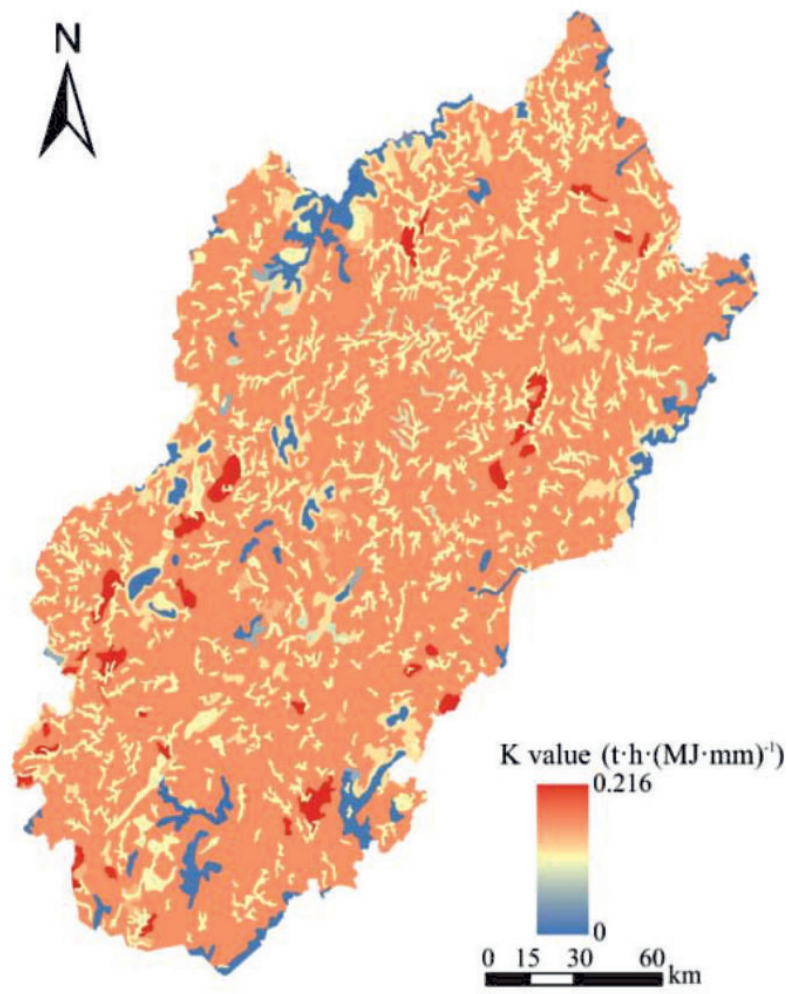

Fig. 4. Diagrams of soil types and $\mathrm{K}$ in the upstream watershed of the Minjiang River; a) Soil types diagram, b) K diagram.

Note: Soil types 1: Dark yellow-brown soil, 2: Lime soil, 3: Black calcareous soil, 4: Purple soil, 5: Acid purple soil, 6: Acid lithic soil, 7: Rhogosol, 8: Acid rhogosol, 9: Mountain meadow soil, 10: Paddy soil, 11: Waterloggogenic paddy soil, 12: Percogenic paddy soil, 13: Gleyed paddy soil, 14: Red earth, 15: Yellow-red soil, 16: Red loam soil, 17: Yellow earth, 18: Loamy soil, 19: Lake or reservoir, 20: Rivers, 21: Sandbank. 


$$
L_{S}=0.08 \cdot \lambda^{0.35} \cdot \theta^{0.66}
$$

...where $\lambda$ is the slope length (m) and $\theta$ is the slope angle $\left({ }^{\circ}\right)$.

Specifically, the slope and slope length data were extracted based on the slope map and slope direction map generated by the DEM elevation model (Fig. 5a) and the 3D hydrological analysis function of ArcGIS. The maps were grid size $30 \times 30 \mathrm{~m}$ after grid pixel conversion to ensure the spatial accuracy of remote sensing data monitoring. Finally, the image of slope and slope length was superimposed, and the terrain factor $\mathrm{L}_{\mathrm{S}}$ calculated is shown in Fig. $5 b$ ).

The soil erosion rate is also greatly affected by vegetation cover, land cover and land use significantly $[14,16,29]$. The vegetation cover and management
(C) factor accounts for the change of land use type and reflects the influence of vegetation cover on soil erosion. Specifically, the $\mathrm{C}$ value represents the ratio of soil erosion under existing land cover conditions to that of the base soil (under standard conditions without any vegetation cover). Higher and denser vegetation cover results in reduced soil loss $[25,26]$. In the area without vegetation cover, the $\mathrm{C}$ factor has a value of 1.0, suggesting that the area is prone to erosion; in the area well protected by vegetation cover, the $C$ value is 0.001 , which means it is not easy to erode; in the area with maximum vegetation function, the $C$ value is 0 , meaning that no erosion occurs. The study area is located in the northern forest area of Fujian Province, where the vegetation coverage rate is above $78.3 \%$ and erosion hardly occurs $[22,28,31]$. Here the $\mathrm{C}$ value is obtained (Table 2) by combining the spatial distribution of land a)

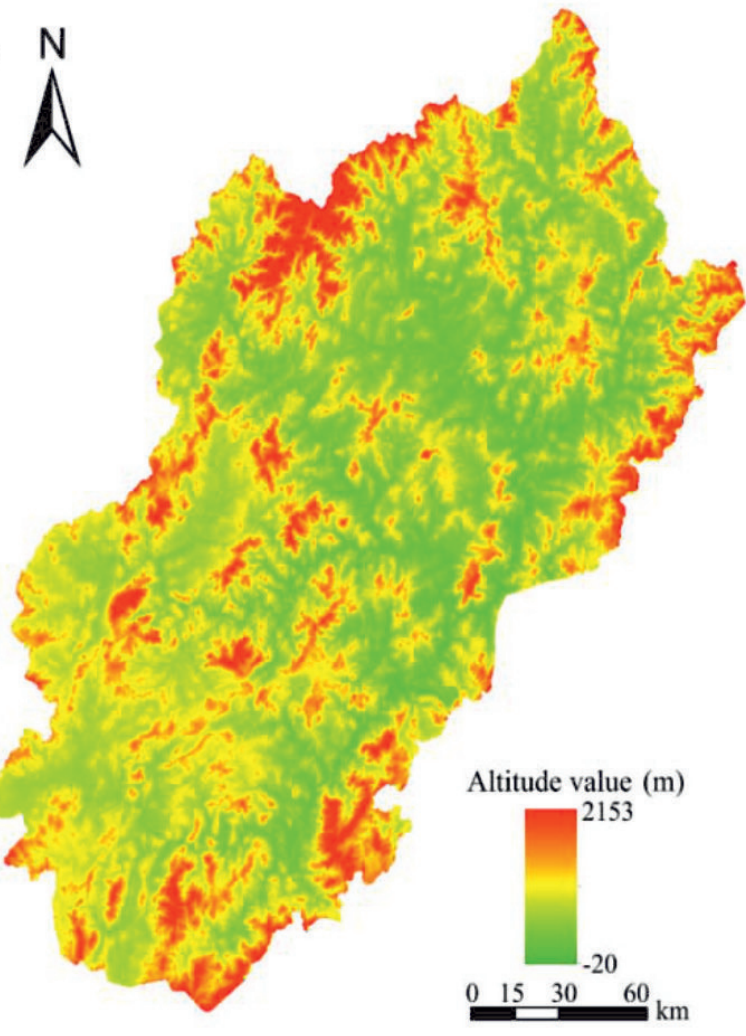

b)

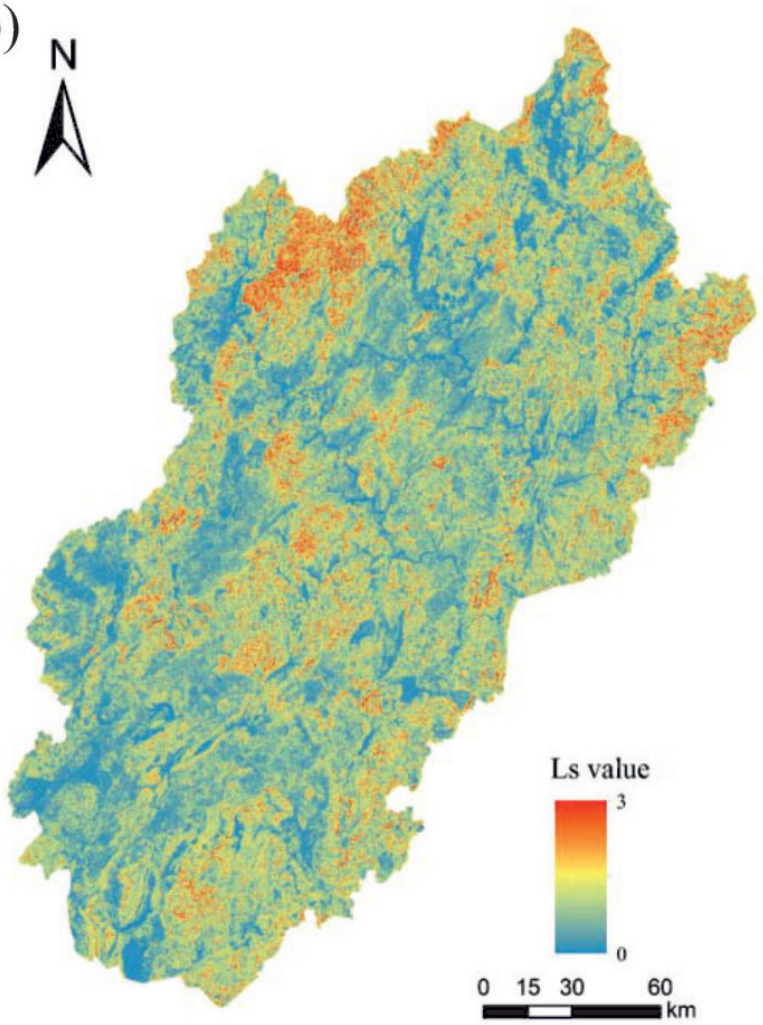

Fig. 5. Diagrams of altitude and $\mathrm{L}_{\mathrm{S}}$ in the upstream watershed of the Minjiang River; a) Altitude diagram, b) $\mathrm{L}_{\mathrm{S}}$ diagram.

Table 3. Values of C and P for different land use types in the studied watershed.

\begin{tabular}{|c|c|c|c|c|c|c|c|}
\hline No. & Land use types & C value & P value & No. & Land use types & C value & P value \\
\hline 1 & Paddy field & 0.18 & 0.01 & 7 & Urban land & 0.20 & 1 \\
\hline 2 & Dry land & 0.31 & 0.35 & 8 & Rural settlements & 0.30 & 1 \\
\hline 3 & Woodland & 0.035 & 0.20 & 9 & Other construction land & 0.23 & 1 \\
\hline 4 & Sparse woodland & 0.017 & 1 & 10 & Unused land & 0.06 & 1 \\
\hline 5 & Orchard & 0.03 & 0.35 & 11 & Waters & 0 & 0 \\
\hline 6 & Grassland & 0.05 & 1 & & & & \\
\hline
\end{tabular}


use types with relevant data, regional characteristics and expert advice. The spatial distribution of $\mathrm{C}$ value is determined (Fig. 6a) with the map of land use types (Fig. 2) and the corresponding $\mathrm{C}$ values (Table 3 ).

The $\mathrm{P}$ value is the ratio of the soil erosion amount under specific support and conservation practices to that of cultivated plots along slopes without any
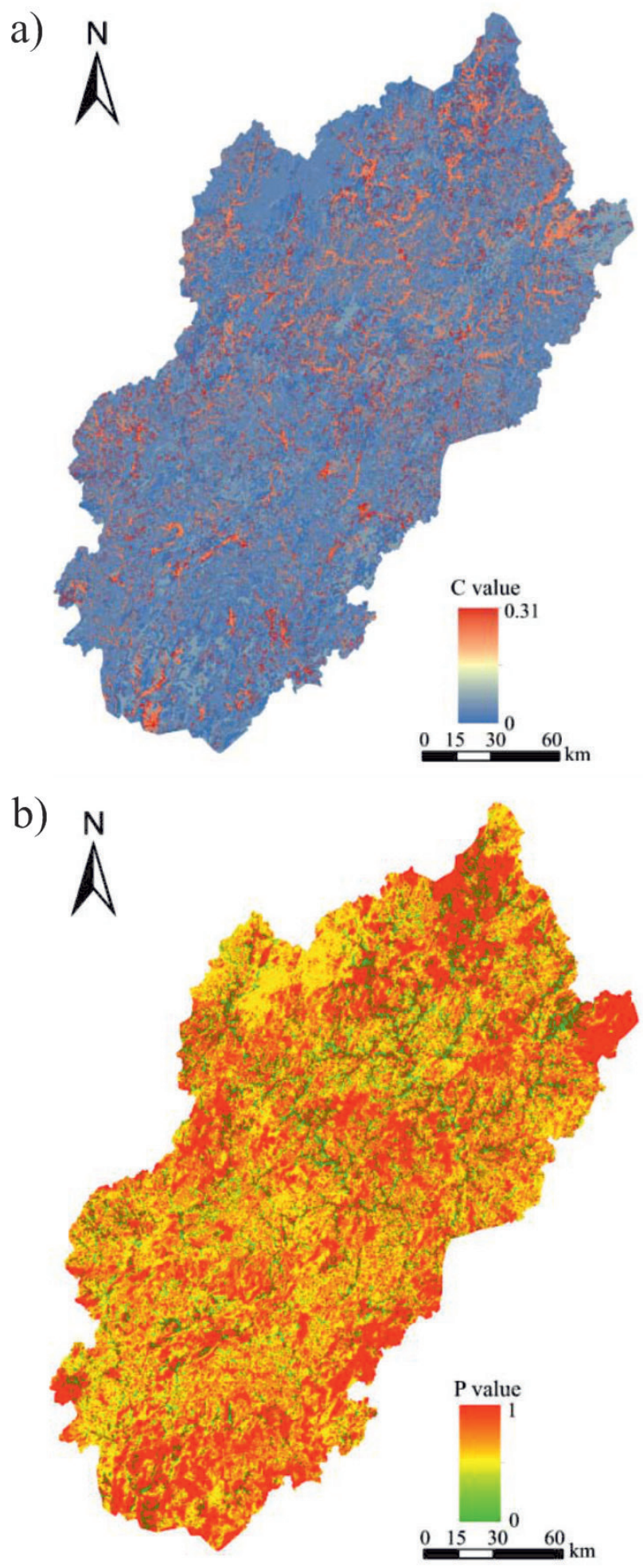

Fig. 6. Diagrams of $\mathrm{C}$ and $\mathrm{P}$ in the upstream watershed of the Minjiang River; a) C diagram, b) P diagram. protection measures, and has a range of 0-1 [16, 29]. Typically the support and conservation practices include terracing, contour tillage, and permanent barriers or strips, which all can significantly decrease erosion risk by reducing the runoff effect through altering drainage patterns and the runoff velocity and concentration. The $P$ values are 0 in the case of perfect conservation practices which completely prevent soil erosion, whereas a value of 1 represents the scenario without conservation practice. The $\mathrm{P}$ values for different land use types are detailed in Table 2. The spatial distribution of $P$ value is drawn (Fig. 6b) by combining the map of land use types (Fig. 2) with their corresponding P values (Table 3).

\section{Spatial Distribution of Soil Erosion}

Using ArcGIS software, the annual soil erosion is calculated following the RUSLE formula with the modeled distribution of each soil erosion factor. Fig. 7 shows the spatial distribution of A value, which falls into different grades defined by the classification standard (Table 1). In the study area, the very lightly eroded area has a percentage of $89.56 \%$ of total area, the lightly eroded area accounts for $9.36 \%$, and very limited areas are moderately eroded $(0.87 \%)$ or worse $(0.21 \%)$. According to a previous study, the percentage of area with very lightly eroded, lightly eroded, moderately eroded and strongly eroded in the upstream watershed of the Minjiang River is $89.91 \%$, $4.76 \%, 2.34 \%$ and $2.99 \%$, respectively [31]. In contrast, in recent years the lightly eroded area has increased significantly (the increased area accounts for $4.60 \%$ of the total studied area, increasing to 1.97 times of the original lightly eroded area), while the area of very lightly eroded, moderately eroded and strongly eroded has decreased. The results show that, on the one hand, due to the increase of urbanization and the impact of human activities in the Upper Minjiang River Basin, the original natural vegetation in the study area is mostly destroyed, and the remaining area is less than $10 \%$ of the original (compare to the study result from $\mathrm{Yu}$ et al. [31]), and distributed in the remote areas of mountains, the area with very lightly eroded has decreased, while the lightly eroded area has increased. Obviously, human activity and related land use change are the primary cause of accelerated soil erosion [7]. On the other hand, with the continuous development of soil erosion protection practices such as closure, prohibition, afforestation, grass planting, and construction of a retaining wall, slag dam and other works, areas with moderate and worse erosion have also declined. Previous studies have shown that most unprotected slopes face stability problems due to erosion, and the soil conservation measures under different land use can increasing the stiffness of the soil surface and decrease both effective upslope eroded area and sediment transport capacity in varying degrees $[32,33]$. 


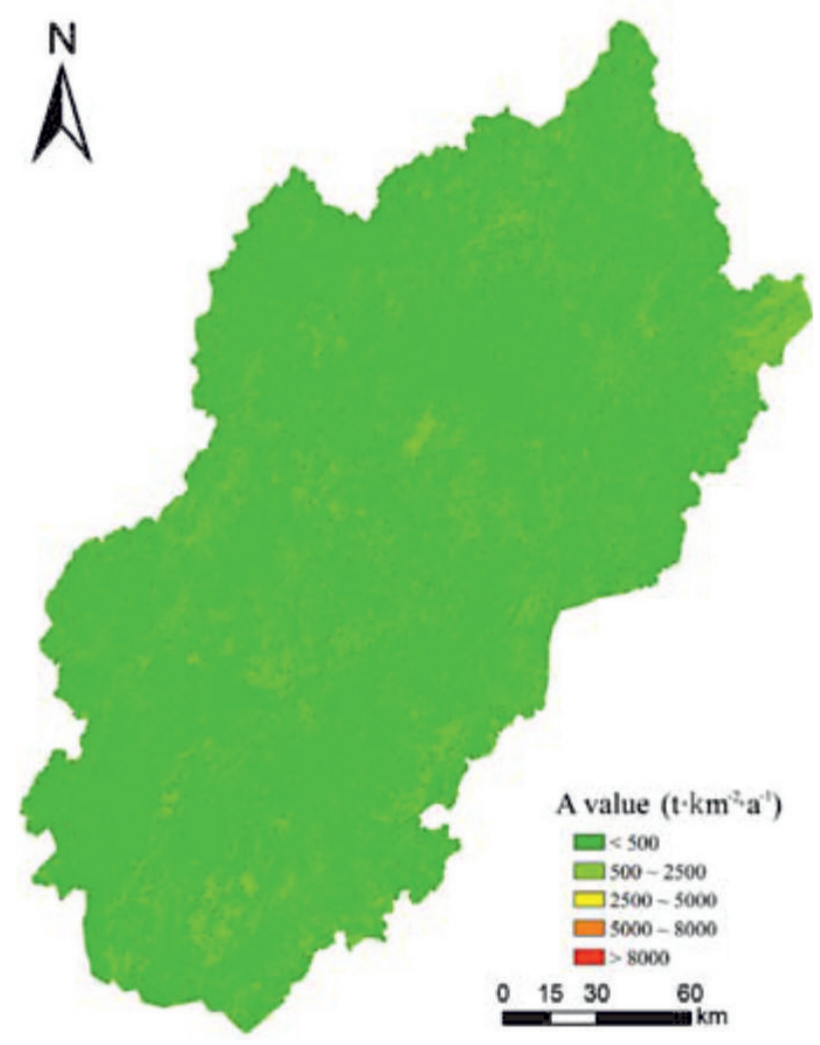

Fig. 7. Distribution of average soil erosion in the upstream watershed of the Minjiang River.

Overall, the soil erosion in the study area shows a wide yet relatively concentrated distribution, namely the spatial aggregation distribution from Fig. 7. To provide scientific data for the prevention and control measures of soil erosion, the area of micro-erosion is neglected, and the distribution of soil erosion in different counties and cities is further analyzed (Table 4). Among all counties and cities, soil erosion at the moderate or higher degrees is the largest in Zhenghe County and Wuyishan City, reaching 692.27 and $511.45 \mathrm{t} \cdot \mathrm{km}^{-2} \cdot \mathrm{a}^{-1}$, respectively. Followed by Shunchang and Changting counties, which have erosion rates of 429.92 and $442.30 \mathrm{t} \cdot \mathrm{km}^{-2} \cdot \mathrm{a}^{-1}$, respectively. All the other counties and cities are less than $400 \mathrm{t} \cdot \mathrm{km}^{-2} \cdot \mathrm{a}^{-1}$. Jianyang City has the least amount of soil erosion $\left(137.83 \mathrm{t} \cdot \mathrm{km}^{-2} \cdot \mathrm{a}^{-1}\right)$. Obviously, the soil erosion rate has large spatial variations, and exhibits great differences in different topographic and geomorphological locations, soil properties, vegetation cover and land use types - especially in hilly and mountainous basins in southern China [6, 7]. Among different counties of the study area, the average annual soil erosion amount of Zhenghe and Wuyishan exceeds the allowable annual soil erosion index $\left(<500 \mathrm{t} \cdot \mathrm{km}^{-2} \cdot \mathrm{a}^{-1}\right)$ in the hilly area of southern China, and far exceeds the allowable soil erosion amount $\left(<200 \mathrm{t} \cdot \mathrm{km}^{-2} \cdot \mathrm{a}^{-1}\right)$ according to the weathering rate of granite in Fujian Province as proposed by Ruan Fushui [34]. Therefore, the prevention and control of soil erosion should be carried out in the study area.

\section{Response of Soil Erosion to Different Land Use Types}

Nowadays, soil erosion interlocked with land use changes has become one of the most important environmental issues in developing countries [35]. Previous studies have shown that land use has become the main influencing factor in explaining the dynamic soil erosion and sediment delivery $[32,36]$. To better quantify the soil erosion intensity of different land use types, the average soil erosion rate of different land use types was further analyzed in the study area. Such analysis was conducted based on the spatial distribution of land use types and the spatial overlap of soil erosion (Fig. 7) in the upstream watershed of the Minjiang River (Fig. 2). The average soil erosion of different land use types were quantified by using the ArcGIS platform (Table 5).

Comparing soil erosion based on land use types (Table 5), we find a significant difference for different land use types in the study area, indicating that land use plays an important role in soil erosion. The order of average annual soil erosion amount in different land

Table 4. Average annual soil erosion of counties and cities in the studied watershed.

\begin{tabular}{|c|c|c|c|c|c|}
\hline Counties & $\begin{array}{c}\text { Erosion rate } \\
\left(\mathrm{t} \cdot \mathrm{km}^{-2} \cdot \mathrm{a}^{-1}\right)\end{array}$ & Counties & $\begin{array}{c}\text { Erosion rate } \\
\left(\mathrm{t} \cdot \mathrm{km}^{-2} \cdot \mathrm{a}^{-1}\right)\end{array}$ & Counties & $\begin{array}{c}\text { Erosion rate } \\
\left(\mathrm{t} \cdot \mathrm{km}^{-2} \cdot \mathrm{a}^{-1}\right)\end{array}$ \\
\hline Pucheng & 381.70 & Shunchang & 429.92 & Changting & 442.30 \\
\hline Songxi & 312.25 & Yanping & 363.31 & Liancheng & 401.95 \\
\hline Zhenghe & 692.27 & Jianning & 303.14 & Yong'an & 405.15 \\
\hline Wuyishan & 511.45 & Taining & 410.34 & Mingxi & 230.77 \\
\hline Jianyang & 137.83 & Jiangle & 355.60 & Sanyuan & 353.62 \\
\hline Jian'ou & 382.32 & Ninghua & 213.01 & Meilie & 338.10 \\
\hline Guangze & 286.45 & Qingliu & 290.44 & Shaxian & 381.29 \\
\hline Shaowu & 390.68 & & & & \\
\hline
\end{tabular}


Table 5. Average soil erosion of different land use types in the studied watershed.

\begin{tabular}{|c|c|c|c|c|c|}
\hline No. & Land use types & $\begin{array}{c}\text { Erosion rate } \\
\left(\mathrm{t} \cdot \mathrm{km}^{-2} \cdot \mathrm{a}^{-1}\right)\end{array}$ & No. & Land use types & $\begin{array}{c}\text { Erosion rate } \\
\left(\mathrm{t} \cdot \mathrm{km}^{-2} \cdot \mathrm{a}^{-1}\right)\end{array}$ \\
\hline 1 & Paddy field & 48.71 & 7 & Urban land & 447.56 \\
\hline 2 & Dry land & 1359.25 & 8 & Rural settlements & 993.74 \\
\hline 3 & Woodland & 124.47 & 9 & Other construction land & 620.44 \\
\hline 4 & Sparse woodland & 398.33 & 10 & Unused land & 2969.53 \\
\hline 5 & Orchard & 1936.88 & 11 & Waters & 0 \\
\hline 6 & Grassland & 706.21 & & & \\
\hline
\end{tabular}

use types was as follows: unused land $>$ orchard $>$ dry land $>$ rural settlements $>$ grassland $>$ other construction land $>$ urban land $>$ sparsewoodland $>$ woodland $>$ pad dy field. This is related to comprehensive factors of vegetation cover, soil erosion resistance, soil and water conservation measures and artificial disturbance intensity under different land use types. Among different land use types, paddy fields are protected by ridges and with the lowest soil erosion rate (the average value is $\left.48.71 \mathrm{t} \cdot \mathrm{km}^{-2} \cdot \mathrm{a}^{-1}\right)$; the surface soil of woodland (forest land) and grassland is well resistant to soil erosion due to vegetation cover and root distribution; other land use types have strong catchment capacity and are more prone to soil erosion.

Previous studies have shown that the soil erosion of various land use types is greatly affected by vegetation cover, and an increase of surface vegetation coverage can significantly weaken the influence of slope and rainfall on soil and water loss. At the same time, vegetation types of forest land also affect the occurrence of erosion: soil erosion is the least in broad-leaved forest, followed by plantation, economic forest, and that the soil loss is the most serious in orchard [6, 37]. The result of the present analysis shows that the average soil erosion of woodland (natural and planted forests with canopy density of more than $30 \%$ ), sparse woodland (forest with canopy density of less than $30 \%$ ) and grassland of studied area is $124.47,398.33$ and $706.21 \mathrm{t} \cdot \mathrm{km}^{-2} \cdot \mathrm{a}^{-1}$, respectively. However, due to the lack of vegetation cover, the surface soil of unused land is easily transported in the form of splash and saltation by rainfall, and forms raindrop splash erosion and rill erosion by surface runoff, thus resulting in a slope erosion several times to dozens of times higher [6, 32]. Therefore, unused land has the most serious soil erosion, with an average erosion rate of $2969.53 \mathrm{t} \cdot \mathrm{km}^{-2} \cdot \mathrm{a}^{-1}$ in a study area.

Moreover, the soil erosion of rural settlements (993.74 $\left.\mathrm{t} \cdot \mathrm{km}^{-2} \cdot \mathrm{a}^{-1}\right)$ is often more serious than that of urban land $\left(447.56 \mathrm{t} \cdot \mathrm{km}^{-2} \cdot \mathrm{a}^{-1}\right)$ in the study area. The average soil erosion rate of the former is more than twice that of the latter, suggesting a buffer effect of economic development and population density on soil erosion. Existing research also shows that the least developed economies have been found to experience the highest estimates of soil erosion rates $[7,38]$.

It is worth noting that there are abundant tea gardens in the study area (northern Fujian), espetially Zhenghe and Wuyishan counties [24]. Long-term tea planting results in soil acidification in tea gardens. At the same time, excessive reclamation and unreasonable cultivation and management methods are easy to cause more serious soil erosion in tea gardens than in other gardens. Therefore, the average annual soil erosion $\left(1936.88 \mathrm{t} \cdot \mathrm{km}^{-2} \cdot \mathrm{a}^{-1}\right)$ in the orchard is second only to that in the unused land of the studied area. A previous study showed that soil erosion in stony/barren/unused land $\left(6030 \mathrm{t} \cdot \mathrm{km}^{-2} \cdot \mathrm{a}^{-1}\right)$ was higher than in tea gardens (1609 $\left.\mathrm{t} \cdot \mathrm{km}^{-2} \cdot \mathrm{a}^{-1}\right)$ in the Kangra region of western Himalaya [39].

\section{Conclusions}

By applying the RUSLE model, this study produces the land use distribution map, the spatial distribution of soil erosion and its changes as affected by land use type in the upstream watershed of the Minjiang River based in the field investigation and using GIS technology. The results show that overall, the soil is only very lightly eroded in the study area, and the overall spatial distribution of soil erosion exhibits an aggregation distribution pattern. Among different counties and cities, Zhenghe County has the largest annual soil erosion, followed by Wuyishan, Shunchang and Changting, and all other counties and cities are with lower soil erosion. Among different land use types, the erosion of unused land, orchard, dry land and rural settlements is more serious, while that of grassland, urban land, woodland and paddy field is less. Such a difference is related to vegetation cover, soil and water conservation measures and the degree of human interference under different land use patterns. Therefore, the results of this study can help identify the soil erosion hot spots and conservation priority areas at local and regional levels.

In Fujian Province, the study area is the key forestry area where the original zonal broad-leaved forests have been replaced by artificial and secondary forests. 
The degradation of vegetation system causes a decreasing function of soil and water conservation, and results in the expansion of soil erosion area. Actually, the study area has great potential risk of soil erosion due to the mountainous and hilly landscape with large terrain gradient, the large rainfall and its concentrated temporal distribution. Therefore, it is important to protect the local forest ecosystem to prevent regional soil erosion.

\section{Author Contributions}

Hongmeng Ye and Weiping Hua are co-first authors; Xuyin Yuan and Hao Yang conceived and designed the experiments; and Changchun Huang, Tao Huang and Hong Wang carried out the method and performed the analysis.

\section{Acknowledgements}

This research was supported by the National Natural Science Foundation of China (41372354, 41673108, and 41773097), the General Program of China Postdoctoral Science Foundation, and the Fujian Provincial Department of Education Project (JAT170591).

\section{Conflict of Interest}

The authors declare no conflict of interest.

\section{References}

1. MHAZO N., Chivenge P., CHAPLOT V. Tillage impact on soil erosion by water: Discrepancies due to climate and soil characteristics[J]. Agriculture Ecosystems \& Environment, 230, 231, 2016.

2. MTIBAA S., HOTTA N., IRIE M. Analysis of the efficacy and cost-effectiveness of best management practices for controlling sediment yield A case study of the Joumine watershed, Tunisia[J]. Science of the Total Environment, 616-617, 1, 2018.

3. NEGASA T., KETEMA, H., LEGESSE, A., SISAY M., TEMESGEN H. Variation in soil properties under different land use types managed by smallholder farmers along the toposequence in Southern Ethiopia[J]. Geoderma, 290, 40, 2017.

4. LI P.F., MU X.M., HOLDEN J., WU Y.P., IRVINE B., WANG F., GAO P. ZHAO G.J., SUN W.Y. Comparison of soil erosion models used to study the Chinese Loess Plateau[J]. Earth-Science Reviews, 170, 17, 2017.

5. FERNANDEZ P., DELGADO E., MÓNICA L.A., JOSÉ M.P. GIS environmental information analysis of the Darro River basin as the key for the management and hydrological forest restoration[J]. Science of the Total Environment, 613-614, 1154, 2018.

6. NABIOLLAHI K., GOLMOHAMADI F., TAGHIZADEHMEHRJARDI R., KERRY R., DAVARI, $M$. Assessing the effects of slope gradient and land use change on soil quality degradation through digital mapping of soil quality indices and soil loss rate[J]. Geoderma, $\mathbf{3 1 8}$, 16, 2018.

7. BORRELLI P., ROBINSON D.A., FLEISCHER L.R, LUGATO E., PANAGOS P. An assessment of the global impact of 21st century land use change on soil erosion[J]. Nature Communications, 8 (1), 1, 2017.

8. YE H.M., YUAN X.Y., HAN L., JA M., JING Q. Risk assessment of nitrogen and phosphorus loss in a hillyplain watershed based on the different hydrological period: a case study in Tiaoxi watershed[J]. Sustainability, 9(8), 1493, 2017.

9. UWIMANA A., VAN A.D., GETTEL G.M., IRVINE $K$. Effects of agricultural land use on sediment and nutrient retention in valley-bottom wetlands of Migina catchment, southern Rwanda[J]. Journal of Environmental Management, 219, 103, 2018

10. WISCHMEIER W.H., SMITH D.D. Predicting rainfall erosion loses, a guide to conservation planning. Agriculture Handbook No. 537 (US Department of Agriculture, Washington, DC), 1978.

11. LAFLEN J.M., LANE L.J., FOSTER G.R. WEPP: A new generation of erosion prediction technology[J]. Journal of Soil and Water Conservation, 46 (1), 34, 1991.

12. RENARD G., FOSTER G.R., WEESIES G.A., MCCOOL D.K., YODER D.C. Predicting soil erosion by water: a guide to conservation planning with the Revised Universal Soil Loss Equation (RUSLE): USDA-ARS handbook. No. 703[M]. Washington, DC: United States Government Printing Office, 1997.

13. MORGAN R.P.C., QUINTON J.N., SMITH R.E., GOVERS G., POESEN J.W.A., AUERSWALD K. CHISCI G., TORRI D., STYCZEN M.E. The European Soil Erosion Model (EUROSEM): a dynamic approach for predicting sediment transport from fields and small catchments[J]. Earth Surface Processes and Landforms, 23 (6), 527, 1998.

14. ZHANG H.D., ZHANG R.H., QI F., LIU X., NIU Y., FAN Z.F., ZHANG Q.H., LI J.Z., YUAN L., SONG Y.Y., YANG S.Y., YAO X.Y. The CSLE model based soil erosion prediction: Comparisons of sampling density and extrapolation method at the county level[J]. Catena, 165, 465, 2018

15. HANCOCK G.R., VERDON-KIDD D., LOWRY J.B.C. Soil erosion predictions from a landscape evolution model - an assessment of a post-mining landform using spatial climate change analogues[J]. Science of the Total Environment, 601-602, 109, 2017.

16. SOMAYEH E., MAHDI M., VAHID M., FARSHAD M. $H$. An improved RUSLE/SDR model for the evaluation of soil erosion[J]. Environmental Earth Sciences, 77 (12), 454, 2018

17. TANG Q., XU Y., BENNETT S.J., LI Y. Assessment of soil erosion using RUSLE and GIS: a case study of the Yangou watershed in the Loess Plateau, China[J]. Environmental Earth Sciences, 73 (4), 1715, 2015.

18. FERNANDEZ P., DELGADO E., MÓNICA L.A., JOSÉ M.P. GIS environmental information analysis of the Darro River basin as the key for the management and hydrological forest restoration[J]. Science of the Total Environment, 613-614, 1154, 2018.

19. LUO C., TAN C., ZHENG Y.J. Long-term prediction of time series based on stepwise linear division algorithm and time-variant zonary fuzzy information granules. International Journal of Approximate Reasoning, 108, 38, 2019. 
20. JIANG H., WANG H., ZHENG Z.H., XU Q.L. Privacy preserved wireless sensor location protocols based on mobile edge computing. Computers \& Security, 84, 393, 2019.

21. XU H.Q. Dynamic of soil exposure intensity and its effect on thermal environment change[J]. International Journal of Climatology, 34 (3), 902, 2014.

22. WANG Y., YANG H., ZHANG J.X., XU M., WU C. Biomarker and stable carbon isotopic signatures for 100 200 year sediment record in the Chaihe catchment in southwest China[J]. Science of the Total Environment, 502, 266, 2015.

23. WU X.L., WEI Y.J., WANG J.G., XIA J.W. Effects of soil type and rainfall intensity on sheet erosion processes and sediment characteristics along the climatic gradient in central-south China[J]. Science of the Total Environment, 621, 54, 2018.

24. YE H.M., YUAN X.Y., ZHOU R., WAN J., XU J. Distribution and environmental significance of phosphorus forms in riparian soils and river sediments of Jianxi Basin, Fujian province[J]. Polish Journal of Environmental Studies, 26 (5), 2331, 2017.

25. FARHAN Y., NAWAISEH S. Spatial assessment of soil erosion risk using RUSLE and GIS techniques[J]. Environmental Earth Sciences, 74 (6), 4649, 2015.

26. ABDO H., SALLOUM J. Mapping the soil loss in Marqya basin: Syria using RUSLE model in GIS and RS techniques[J]. Environmental Earth Sciences, 76 (3), 114, 2017.

27. EFTHIMIOU N., PSOMIADIS E. The significance of land cover delineation on soil erosion assessment[J]. Environmental Management, 62, 383, 2018.

28. HUANG Y.H. Soil Erosion and Control in Southern Fujian [M]. Beijing: China Agricultural Press, 2002 [In Chinese].

29. TANG Q., XU Y., BENNETT S.J., LI Y. Assessment of soil erosion using RUSLE and GIS: a case study of the Yangou watershed in the Loess Plateau, China[J]. Environmental Earth Sciences, 73 (4), 1715, 2015.

30. ZHANG H.M., WEI J.C., YANG Q.K., BAARTMAN J.E.M., CAI L.T., YANG X.M., LI S.Q., YU J.T., RITSEMA C.J., GEISSEN V. An improved method for calculating slope length $(\lambda)$ and the LS parameters of the Revised Universal Soil Loss Equation for large watersheds[J]. Geoderma, 308, 36, 2017.
31. YU K.Y., LIU J., LAI R.W., QI X.L. Quantitative estimation of water and soil erosion from Minjiang Watershed based on Geomatics[J]. Journal of Central South University of Forestry \& Technology, 29 (4), 54, 2009 [In Chinese].

32. FANG H.Y. Impact of Land Use Change and Dam Construction on Soil Erosion and Sediment Yield in the Black Soil Region, Northeastern China[J]. Land Degradation \& Development, 28 (4), 1482, 2017.

33. BOARDMAN J., VANDAELE, K., EVANS R., FOSTER I.D.L. Off-site impacts of soil erosion and runoff: why connectivity is more important than erosion rates[J]. Soil Use and Management, 35 (2), 245, 2019.

34. RUAN F.S., WU X.H., SHI Y.Z., XU J.J. Study on permissible soil erosion in Granite area of Fujian Province[J]. Soil and Water Conservation in Fujian, (2), 26, 1995 [In Chinese].

35. MOGES D.M., BHAT H.G. Integration of geospatial technologies with RUSLE for analysis of land use/cover change impact on soil erosion: case study in Rib watershed, north-western highland Ethiopia[J]. Environmental Earth Sciences, 76 (22), 765, 2017.

36. QUIÑONERO-RUBIO J.M., NADEU E., BOIX-FAYOS C., VENTE J.D. Evaluation of the effectiveness of forest restoration and Check-Dams to reduce catchment sediment yield[J]. Land Degradation \& Development, 27 (4), 1018, 2016.

37. JOURGHOLAMI M., ABARI M.E. Effectiveness of sawdust and straw mulching on postharvest runoff and soil erosion of a skid trail in a mixed forest $[\mathrm{J}]$. Ecological Engineering, 109, 15, 2019.

38. HAREGEWEYN N., TSUNEKAWA A., POESEN J., TSUBO M., MESHESHA D.T., FENTA A.A., NYSSEN J., ADGO E. Comprehensive assessment of soil erosion risk for better land use planning in river basins: case study of the Upper Blue Nile River[J]. Science of the Total Environment, 574, 95, 2017.

39. KUMAR A., DEVI M., DESHMUKH B. Integrated remote sensing and geographic information system based RUSLE modelling for estimation of soil loss in Western Himalaya, India[J]. Water Resources Management, 28 (10), 3307, 2014. 
